for the generosity of interpretation of a 'lapidary inscription', Champollion has no claim to the honour of first penetrating into the mysteries of the writing of ancient Egypt. 'That honour, beyond all question, belongs to our versatile countryman, Thomas Young. In 1819, Young published an article, "Egypt", in the supplement to the "Encyclopædia Britannica", in which he gave a list of alphabetic and syllabic characters, an article which has been described by Sir E. A. Wallis Budge as "practically the foundation of the science of Egyptology". In 1821, two years later, Champollion published a treatise in which he shows not the slightest trace of knowledge of anything alphabetic in hieroglyphic or hieratic characters ; Champollion's publication of an alphabet dates from 1822. Concerning Champollion's alleged attempt to suppress his unfortunate work of 1821 , we need say nothing here; the whole story of the Rosetta Stone and the decipherment of the hieroglyphic characters was discussed some years ago in an article in Nature (April 30, 1932, p. 638). It is sufficient here to say that the inscription on the tablet to the memory of Young in Westminster Abbey states no more than the bare truth when it describes him as the one who "first penetrated the obscurity which had veiled for ages the Hieroglyphics of Egypt".

\section{Recent Acquisitions at the Science Museum}

Among the objects recently placed on exhibition in the Science Museum, South Kensington, is a model of the complete lay-out for a 120-ton 10,000 horse-power Mond gas producer plant with ammonia recovery apparatus which has been lent by the Power-Gas Corporation, Ltd. Mr. Edward J. Willis, an American authority on astronomical navigation, has sent from the United States an example of a navigating machine which was invented by him and constructed at a cost of about $£ 300$. The machine solves problems in spherical trigonometry connected with navigation. An example of Selling's calculating machine which has long lain neglected in the stores of the Imperial College of Seience and Technology has been lent to the Museum for exhibition. The machine was invented fifty years ago and made ingenious use of the 'lazy tongs' mechanism in order to perform multiplication and division. A representative selection of fourteen stone (chert) weights and a plaster cast of a fragment of a linear measure, all found in excavations at Mohenjodaro, Harappa, and elsewhere in northern India-relics of a civilization of c. 3250-2750 B.c., that formed great cities along the Indus valley, contemporaneous with the ancient Egyptian first to fifth dynasties, and the ancient Sumerian kingdoms in Mesopotamia--have been presented by the Archæological Survey of India.

\section{Frontier System in Roman Scotland}

A Further effort to settle the question of the number and character of the occupations of the Roman fort of Birrens, near Ecclefechan, Scotland, is being made by excavations now proceeding in charge of Mr. Eric Birley, of the University of Durham.
The problem to be solved is whether the occupation of the fort was part of the organization of the Antonine Vallum, as Sir George Macdonald has suggested, or whether it is to be related to Hadrian's Wall, as the Dere Street forts to the east recently have been shown to be by Mr. Ian Richmond's excavations. Two periods of occupation separated by a destruction were demonstrated in 1925 by excavation, but the examination of the stratification was not, nor was it intended to be, exhaustive. Search for further evidence is now being made, and with this object excavations are proceeding at two points down to the subsoil for a thorough examination of the stratification and the pottery. Up to the present, a section in the retentura of the fort, it is reported in The Times of August 10, has shown that a wooden building and two of stone preceded the two periods, of which evidence was found in excava. tions made in 1895. The wooden structure is assigned to the latter part of the first century and it is said that traces of Agricola have been found; while the two stone periods which follow are thought to belong to the Antonine occupation. Under the earlier of the two periods previously known, two vessels have been discovered, for which there are parallels from Hadrian's Wall. A second excavation in the protentura has been more fruitful as a source of pottery and other finds, including a large piece of a cut-glass bowl, of which a fragment was found in 1895. Excavation at the west gate has exposed what is described as "the worst Roman masonry so far found in Scotland".

\section{Archæological Finds in Iraq}

DR. HENRI Frankfort's assiduity in making known to the public at an early date any points of special interest arising out of the excavations of which he has been in charge, season by season, is worthy of all commendation, especially since he became field director for the Oriental Institute of the University of Chicago at Tell Asmar, the ancient. Eshnunna. The important and extensive operations of the Oriental Institute in the field of the Ancient East possibly are not so widely known, outside the circle of specialists, as they deserve. In his report on the results of the past season (The Times, August 1), Dr. Frankfort mentions a number of finds of exceptional interest. As is generally known, one of the objects to which he has given special attention at Tell Asmar and on the neighbouring site of Khafaje is the problem of the early relations of Mesopotamia with both the Indus Valley and the Mediterranean. On both these questions he is able to record new and important evidence, in the former instance pointing to a more intimate relation than the purely commercial connexion, which is all that it has been possible to infer from previous finds. In a temple on a new site, Tell Agrab, the expedition has found among a quantity of interesting material some remarkable examples of stone vases with surprising sculptures. Among these is one fragment which shows the sculptured figure of a humped bull standing before a manger and enclosed in the poles of arches which support a roof. Not only is this a 